\title{
Let's Solve It: Designing an Interactive Online Forensic Science Lab
}

\author{
Gina Londino-Smolar \\ Indiana University Purdue University Indianapolis
}

\author{
Carrie Hansel \\ Indiana University
}

Online STEM laboratories are possible for every learner. The design of an online forensic science laboratory course can be as effective as traditional and other online courses. The theory behind teaching tools developed should be considered throughout the design process. Using the learning management system to engage students with the course material, each other, and the instructor is also key in online courses. Difficult tasks were conquered by using Universal Design for Learning (UDL) to identify barriers and create solutions. Creation of hands-on and virtual labs along with accessibility concerns of web-based content is possible in the online environment.

Keywords: online laboratory, science lab course, learning technologies, instructional design

\section{INTRODUCTION}

The effects of online education reaches around the world (Hartnett, 2012), giving it the label as a significant agent of change to education (Simonson, et al., 2011). Over 248 studies show its comparable effectiveness to traditional courses (Simonson, et al., 2012) with other studies reporting that on average, online students perform as well or better than their counterparts in traditional classroom settings (Bernard, et al., 2014; Brinson, 2015; Lou, et al., 2006).

Online education's effectiveness coupled with increasing student demand for online courses fuels the exponential growth of online learning opportunities (Hartnett, 2012). The growth may be due to the flexibility offered by online learning provides opportunities to learners who have various life situations (Cummings, et al., 2013). The results of this growth have led to an increased enrollment in online higher education that outnumbers other higher education growth by 10-fold (Wavle \& Ozogul, 2019).

This increased online enrollment has raised the demand especially for online general education core courses that can be included in multiple degree programs. While many lecture style courses are easily adapted to the online environment, there is a lack of laboratory courses offered solely online despite that many degree programs require students to complete a laboratory experience. To comply with the demand, an online laboratory course in forensic science was developed and available for all learners. Online laboratory courses have been developed in multiple science disciplines and have been successful (Moosvi et al., 2019). Throughout the design process, the focus centered on active learning strategies, both formative and substantive assessments, as well as face-to-face and online engagement in the classroom. This can be 
especially needed in science courses (Chen et al., 2018) to make sure that students are connecting to the content, learn key concepts, and apply their understanding to case examples.

The design of the course learning experiences and environment can favorably impact conditions of learning (Merrill, 2013). Although there is no specific way to design an effective learning environment (Bransford, et al, 2004), one can ask the right questions to gather the necessary learning, teaching, and design principles to ensure that a learning environment supports the desired learning experience and outcomes. One strategy is to research design practices firmly grounded in the literature or the concept of "grounded design", which uses a systematic approach to implementation that ensures the process and procedures follow established theory and human learning research (Land et al., 2012). The primary grounded theory used for this course is authentic learning environment design (Herrington \& Oliver, 2000); whereas, the supporting grounded theory is universal design for learning (UDL) environments (Basham et al., 2013), which focuses on the principle of multiplicity, which uses representation, expression and action, and engagement. The theoretical principles resulted in a focus on an authentic learning experience while also meeting the needs of learners in a variety of ways to set all students up for success. The authentic course components reflect real-world knowledge and tasks supplied by experts and multiple perspectives while encouraging learners to reflect meaningfully on what they have learned (Herrington, et al., 2014) while UDL engages students with the content using multiple methods, represents the content with multiple learning tools, and utilizes both formative and summative assessment to record learning through action and expression (Rogers-Shaw, et al., 2018).

Using these theoretical principles, the course instructor, consultants from the teaching center and the eLearning Design and Services (eDS) team collaboratively created this online lab to meet the student enrollment needs because the physical laboratory space had reached scheduling capacity. The integrity of the online lab learning objectives remain the same as the in-person lab but have been modified to suit the in-home space through virtual labs, simulations, the use of lab kits mailed to students' homes, and proctored exams. Making sure students have the same experience in both the online and face-to-face environment was key in the development of the course. There are misconceptions (Moosvi et al., 2019) about online laboratory experiences and the goal is to show how these can be overcome in the science disciplines. Examination of misconceptions and barriers that one may think would limit the experience for the students were addressed and solved throughout the development process using Moore's (2010) three guiding questions: What do learners need to be able to do at the end of the course? What barriers might prevent their success? How can course design use the principle of multiplicity in terms of content format, engagement, and students' interactions and expression?

In this article, the design process and course organization will be summarized with examples in how best practices were used during the process to ensure accessibility for all learners.

This course design was specifically developed to be inclusive and accessible for all learners, which included making accessible options for all laboratory experiments to reach all students that want to investigate forensic science. The development process and barriers that were overcome to expose all learners to the course material will be explained.

\section{DESIGN OF LEARNING ENVIRONMENT}

One key consideration for the design of the learning environment was that the target audience are unfamiliar with foundational laboratory skills and possibly have never taken a fully online course. To address this need, the course design creates an environment using resources and a guided structure to ensure student success (Gravel et al., 2017). This includes scaffolding learning materials and monitoring student assessment throughout the course. Upon entering the course, the homepage that greets visitors visually with a welcome banner, as seen in Figure 1, that attempts to emulate the forensic science feel. 


\section{FIGURE 1 \\ HOMEPAGE WELCOME BANNER}

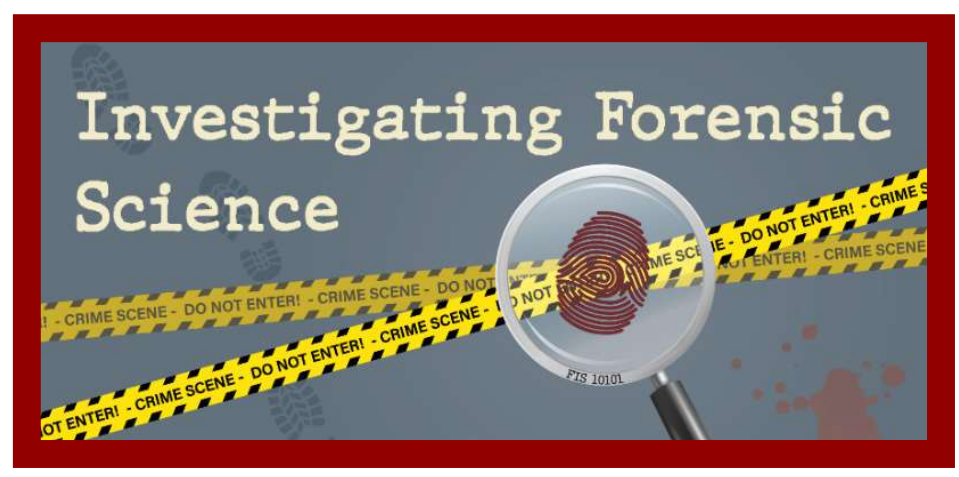

Additionally, the instructor greets students with a welcome paragraph, an introductory video welcoming student to the course, and contact information so that students know immediately how to reach the instructor. Following that welcome, instructions are provided to guide students to the "Getting Started" module, the syllabus, and actions that must be taken immediately to ensure that they receive their lab kits on time for course activities. Next, Figure 2 shows a grid providing the names and links to each course module, which gives students a quick view of what they will be learning as well as a way to easily navigate to the module they are ready to work on. Finally, students are given information on how to obtain technical support 24 hours a day, seven days a week. In an online course, technical issues can arise. Since online students can join from anywhere around the world at any time of day, it is difficult for an instructor to provide guidance as quickly as needed. By leveraging university-provided resources, students can easily obtain what they need when they need it. This also allows the instructor to spend on what she knows best the content, teaching, and student learning.

\section{FIGURE 2 \\ HOMEPAGE MODULE GRID}

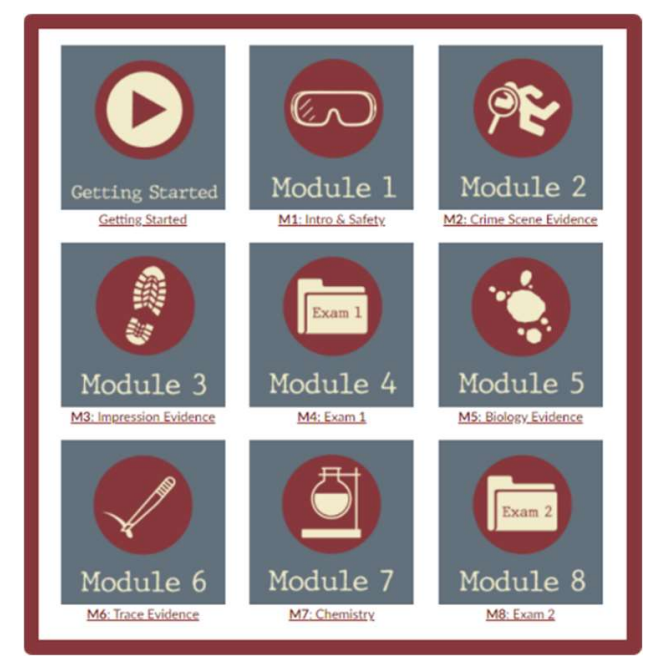

\section{Scaffolding Techniques}

Another method for supporting students is scaffolding. Belland (2014) describes scaffolding as a support provided by an instructor that ensures students can participate in a task while also learning a skill from the experience. This technique is used several times throughout the online course to ensure student success. The course navigation is offered on every page has been ordered to provide the most important 
information in rank order: Home, Announcements, Syllabus, IT Support 24/7, Modules, IU eText (Unizin Engage), People, Chat, and Boost. The final item - Boost 7 - is a mobile app that students can sign up for to push Canvas notifications and assignment reminders to students' phone to help them to manage their course requirements. No instructor involvement is needed.

To begin, students are directed to review the syllabus (Figure 3) that outlines the course requirements and the schedule for the 8-week course. A downloadable version of the syllabus is linked in the page, making it easy for the students to find whenever they need it. In addition, key elements of the syllabus are highlighted to answer the most frequently asked questions as well as those that students may miss within the text of the full syllabus. HTML anchor tags allow learners to click on a topic and then click on a "backto-the-top" button.

\section{FIGURE 3 \\ CANVAS SYLLABUS PAGE}

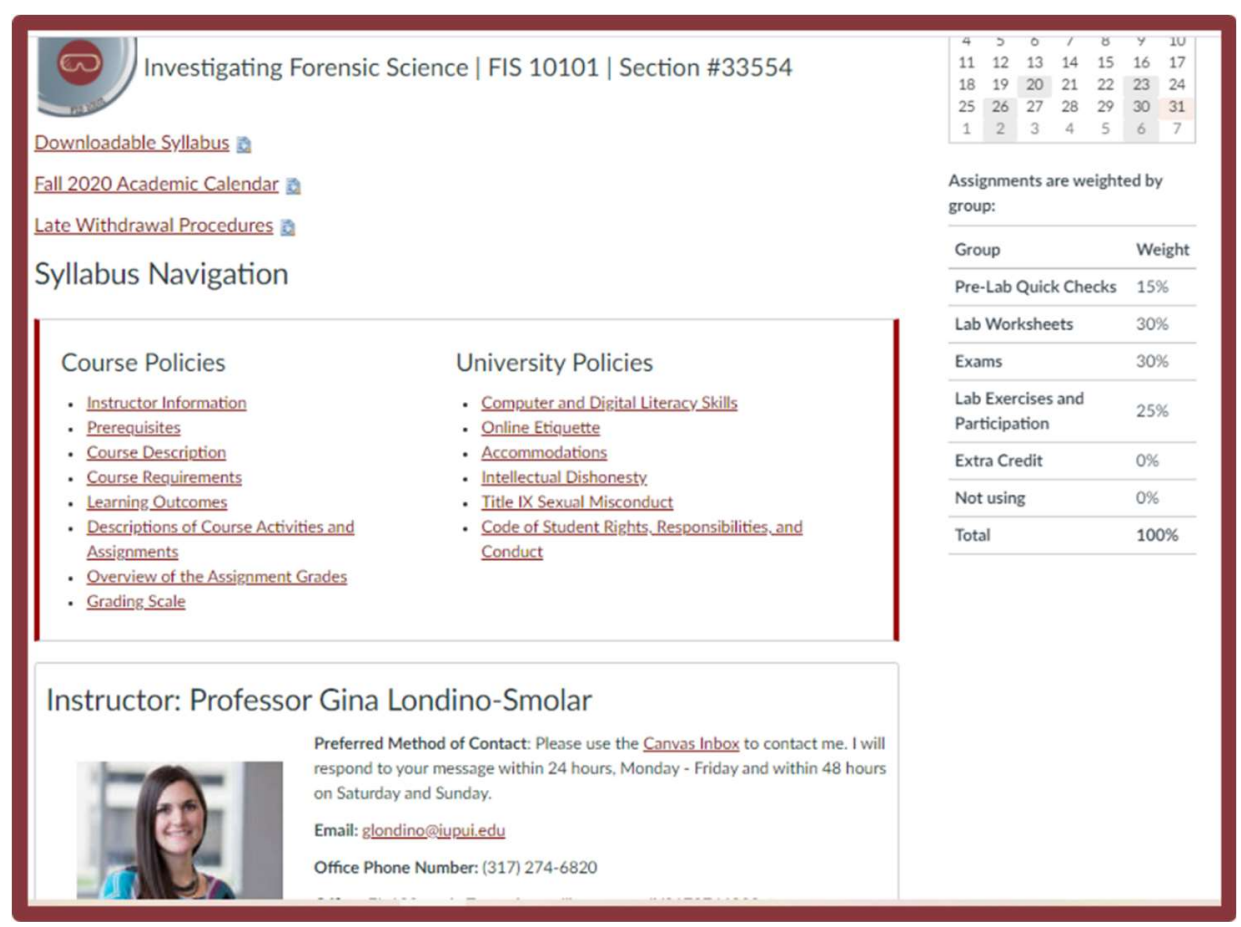

Besides the syllabus, students are directed to the "Getting Started" module. It provides details on the course, the instructor (to establish instructor presence), and how to get started with the course. In this section, students receive detailed information on how to use Canvas modules, which includes starting with the overview page, assignments, and everything for each week is provided in this one place. The content can be navigated using previous and next buttons while inside of the content or that they may go to the modules view and see everything they will be doing in list-form.

As the student navigates through the "Getting Started" module (Figure 4), instructions on how to use the main technologies of the course are given as shown. These include "IU Google Set Up", "Lab Overview", and "Technology and Canvas Start Page". This module is located at the top of the module view so that students can readily access the materials every time they enter. Additionally, students learn about available resources that will aid their success: Announcements, Modules, Syllabus, Chat, Schedule, Grades, and Canvas Inbox. Finally, to ensure that students receive important information, students take a quiz on the main objectives of the course, complete an acknowledgement of reading how to obtain accommodation support if needed, order the lab kit quickly enough to ensure they receive the materials in time to complete the activities, and conduct a review of the lab kit to make sure the kit contains all required materials. 


\section{FIGURE 4}

\section{GETTING STARTED MODULE}

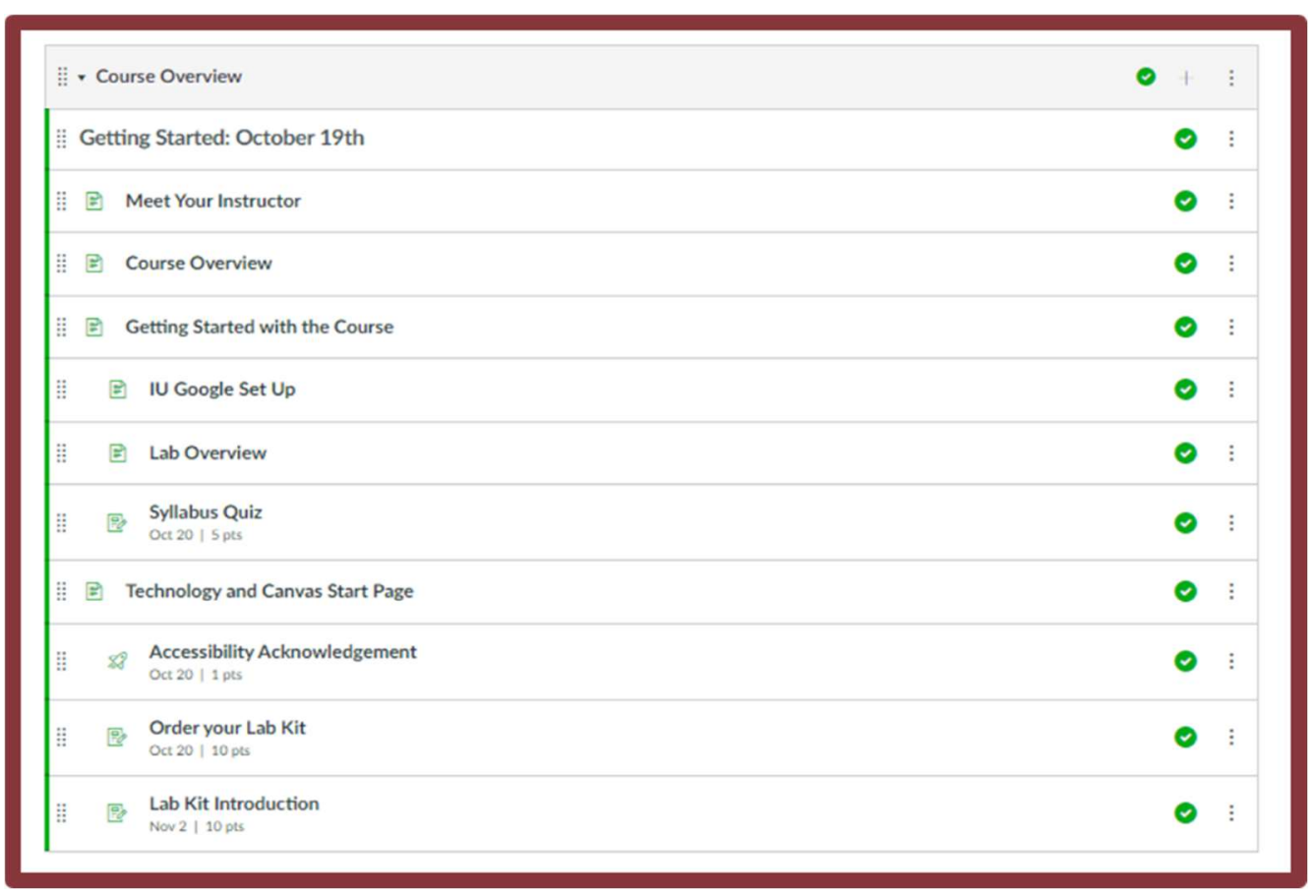

Because students enrolled in this course are non-science majors, scaffolds have been provided to help students obtain the necessary skills to conduct the experiments within their home setting. First, when students open the course homepage, a red box provides instructions on how to order the lab kit and a timeline for when they should be ordered to make sure they have the materials in time to start on the first hands-on lab. Second, in the "Getting Started" module, assignments are given for ordering the kit and for reviewing the kit to make sure everything arrived for every upcoming experiment. Third, the instructor created a video of how to go through the kit, what should be included, and explains what each item is so that students can better complete the assignment. Finally, students complete module 1, which provides lab safety guidelines, provides a tour of a real crime lab, and a scaffolded practice exam to better prepare students for the proctoring aspect of taking an exam for the course.

\section{Monitoring Student Assessment}

Another technique for supporting learners is ensuring that assessments measure the desired course outcomes and that structures are in place to make sure learners understand what they are being asked to do. According to Merrill (2013), assessment is a tool that allows instructors to figure out what students have learned in the course and can reproduce through a task. This course uses a few different forms of assessment. First is the use of a low-stakes formative assessment in the form of Quick Check questions. These are used throughout the module to quiz students on key concepts that will be necessary to successfully complete the higher-staked assessments in the form of lab worksheets, a discussion forum, and an exam. Second is the use of virtual lab activities that can be attempted multiple times to ensure that students can successfully complete the activity. Third is the use of lab worksheets where students enter their findings of all of the lab exercises - hands-on and virtual - in an authentic report form. Fourth is the use of optional practice exams to help students prepare for the exams. Finally, is the use of exams - each exam covering half of the course materials. The variety of assessments evaluate students' content knowledge and their ability to apply the concepts.

Prior to each lab, students are given module learning objectives, readings, resources, and materials to prepare for the lab. Before beginning the lab experiments, a pre-lab formative assessment is given in the 
form of low-stakes questions, Quick Checks. Students can take these Quick Checks until they receive a $100 \%$ or a score that they're happy with. During the labs, students are given detailed instructions, have access to resources and pre-lab materials, and a lab worksheet that guides students through the learning process. Finally, students are given optional practice quizzes to prepare for each of the two course exams. This provides guidance in exam expectations.

A variety of assessment tools are used throughout the course, including Google Docs, reflective discussions, and knowledge-based exams. Fully online laboratories are now a possibility and gaining popularity for non-science major courses to increase enrollment with students who want to complete courses online.

An additional structure for ensuring learners' understanding of assessment criteria is the use of the Transparency in Learning and Teaching (TILT) format, which is used in all of the course assignments, activities, and discussions. Winkelmes (2016) describes this process as providing students with why they are doing the activity (Purpose), what they're going to do (Task), and how they will know that they are successful (Criteria). This tactic makes the assignment more meaningful to the learner and has been shown to increase success (Winkelmes et al., 2016). Further, each assignment and discussion have rubrics (Figure 5) describing how the instructor will grade so that students will know how to successfully complete the activity.

\section{FIGURE 5 DISCUSSION RUBRIC}

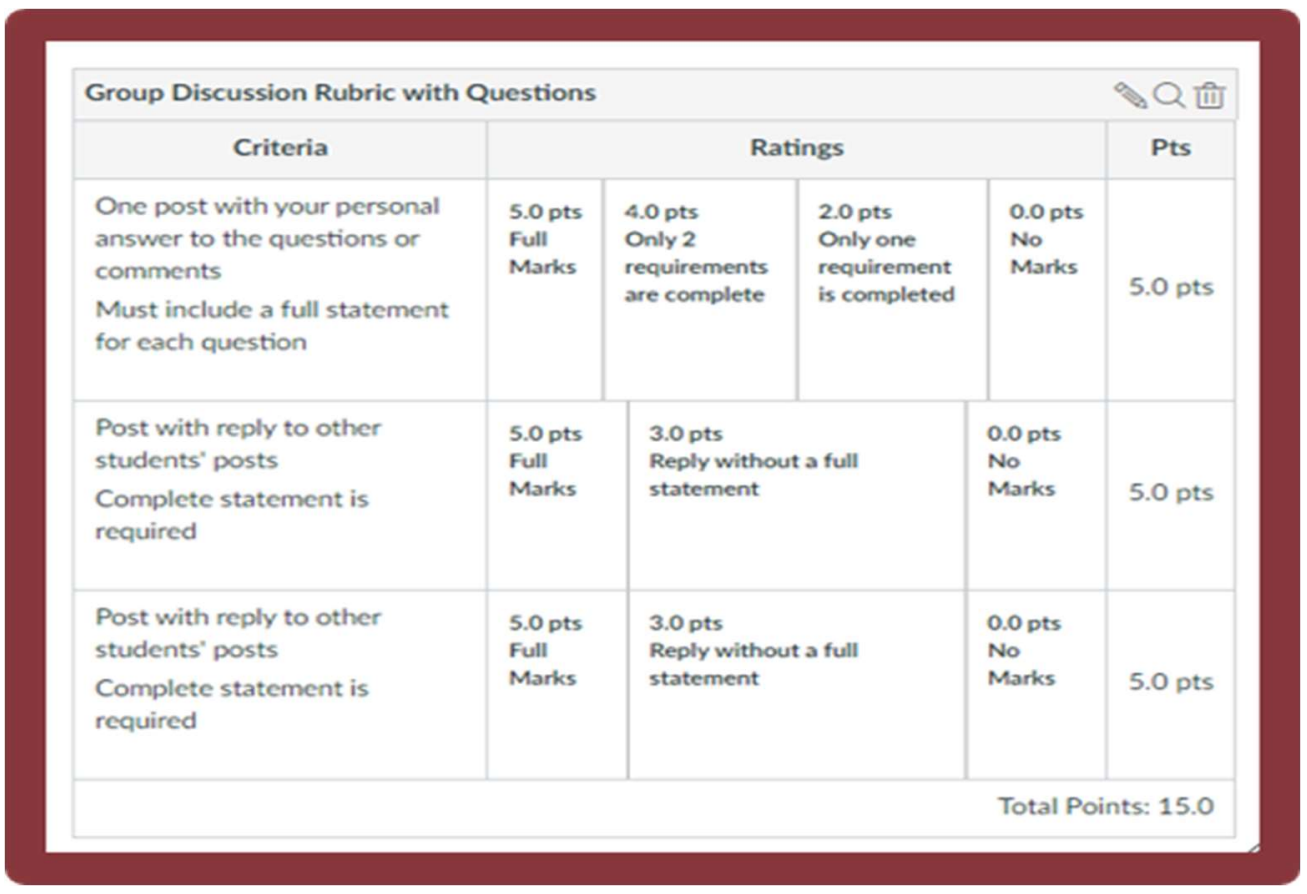

Students need connection with the course instructor, even in asynchronous courses. Timely feedback provides an opportunity to connect with students and increase overall student satisfaction in the online realm (Ellis \& Barnes, 2020), which also applies to an online laboratory course. Also, each week the instructor provides a weekly recap announcement of the previous module's activities as well as an introduction to what students will be doing for the upcoming week. This is solidified with the weekly overview and module introduction video where students can find an outline of everything they will be doing and the highlights about the topic. 


\section{ONLINE LABORATORY COURSE DESIGN}

Traditional laboratory courses are resource-intensive and include in-person interactions both from the instructor and the students (Theyßen, et al., 2016). To provide learners with a similar experience to the traditional lab courses, the design of the online laboratory course used the grounded design frameworks, creating an authentic learning environment (Herrington et al., 2014; Davenport et al., 2018) and universal design for learning (UDL). Additionally, the design incorporated Merrill's (2013) instructional strategies of presentation, practice, demonstration, and application when developing key learning materials for the online lab course. Presentation consists of strategies for students to repeat information or focus attention on a topic, this was done through lecture material and readings. Practice includes asking students to remember the information, which was done through low-stakes questions and exams. Demonstration strategies show students how to do something which was created by virtual and hands-on learning activities. Application has the students do or apply the information, this includes answering post-lab questions or offering opinions in a discussion board. These techniques were used in the development of the online laboratory course and will be discussed.

\section{Introduction to the Course}

Investigating Forensic Science Laboratory is a 100-level, non-science major laboratory course developed first to introduce forensic science to students that may be required to complete a laboratory course as a part of their degree requirements even though they are not science majors. This is becoming more common throughout universities by having a general education core curriculum ensuring to have wellrounded graduates. As a general education core course at Indiana University, the course meets specific state standards and is included in the core set of courses undergraduate students can take to meet certain requirements. This has caused an increase in enrollment as well as a wide variety of learners enrolled, including non-traditional students, non-science students, and students with accessibility needs; currently the course is only offer through one of our many campuses, the goal would be to open this course across our regional campuses for all students.

The course is a substitute option instead of the common laboratory courses such as chemistry and biology. Currently the course is offered during the fall, spring and summer terms with roughly 300 students per academic year. The fall and spring terms are typically 16-week and 8-week sessions with the summer sessions being 6-weeks. The online version of the lab course was developed to increase enrollment without using limited space which is at the maximum capacity both fall and spring semesters. The online version of the course was first taught in the 2020 spring semester, during the first 8-weeks, offered both summer sessions over 6-weeks, and both fall and spring semester during the 2020-2021 academic year during a 16week session.

The online lab course includes both hands-on and virtual experiments that students are required to complete without having to come onto campus. The course was intentionally developed to give the online students similar experiences as the face-to-face students in constructing laboratory experiments, generating data, and interpreting results. All the learning material is in the in one location, the learning management system.

The structure of the course consists of an overview page outlining the weekly readings, activities, and deadlines. Following the overview, students read through course material, answer embedded interactive question activities designed to help them to grasp the important concepts. Students can complete these multiple times to ensure they know the information. Next, students engage in both hands-on and virtual lab exercises developed to provide similar laboratory experiences to the face-to-face course. Students document their observations and answers to critical thinking post-lab questions in lab worksheets designed using Google Docs. Interactive videos with real forensic experts, hands-on lab kits, explosive demonstrations,

and 3-dimensional bullet images are examples this course uses to engage students with the content. After finishing the lab activities, students apply their new knowledge by participating in group discussions on real-world forensic issues surrounding the topic covered in the unit. Lastly, students are given an opportunity to complete practice questions before completing the course exams. 


\section{Using the Learning Management System: Learning Technologies and Organization}

One misconception is that students do not need to engage in an online course but simply need to read materials and then complete an assignment. In reality, students must engage with the course which especially important in an online classroom. Just reading or listening to lectures is not enough to engage students with the material, each other or the course instructor. Using the learning management system (LMS) to create a social community where learning can happen, making this a place for all students to learn, grow, develop and share (Szeto \& Cheng, 2016). Social interaction plays a vital role in achieving course learning goals and in engaging students in an online course (Sher, 2009). There are three types of interaction (Sher, 2009):

- Student to Student: Within the learning community, students need an opportunity to collaborate and discuss what they're learning. This social activity allows them to view the material from other students' perspectives and learn concepts together. To activate this conversation on a regular basis, every module included a discussion forum based on real-world cases that related to the module.

- Student to Instructor: Another key aspect to establishing a learning community includes the instructor who teaches, guides, and focuses students' attention on the key concepts and takeaways. This took the form of weekly recaps and announcements.

- Student to Learning Materials: The final interaction involves having students actively engage with the materials. This is very important in a laboratory course.

Having students interact with the learning materials was an important aspect of developing the online laboratory course. Therefore, the course included a variety of ways for students to learn with the material, check their understanding, submit assignments and also communicate with other students in the class. The LMS assisted with all these types of interactions.

Other course features are the use of interactives to provide learners with opportunities to participate in more authentic contexts, allowing students to interact with the course learning material. These activities allow students the chance to actively explore and practice in a low-stakes environment with feedback to help address misconceptions. The first is the crime scene virtual lab seen in Figure 6 with an interactive crime scene where learners can scan the whole room where the crime took place as well as a branching scenario where learners apply the concepts learned in reading and other content. Students click through the activity and are given a series of choices of how they should conduct each part of the investigation. It allows them to retry if they have errors. Another lab simulation is the serology matching activity which also allows learners to apply what they've learned and have multiple tries in a low-stakes learning environment. Also, there's an activity where students can match physical evidence. In addition, there are hot spots, see in Figure 7, where learners can review different pieces of evidence and learn more about the key characteristics that experts examine, such as fingerprints, fire debris, and hair. 
FIGURE 6

CRIME SCENE BRANCHING ACTIVITY

Virtual Crime Scene Investigation

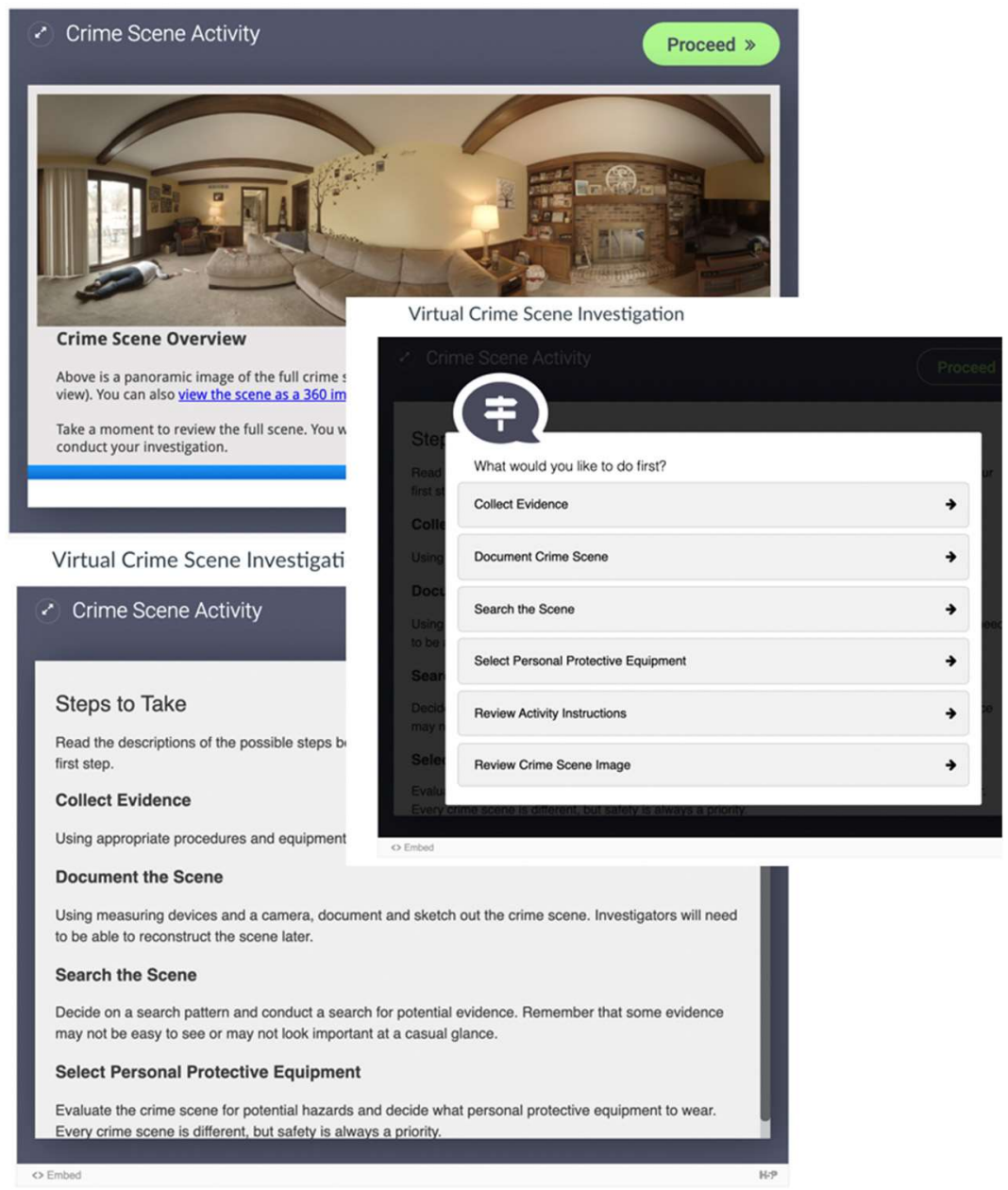

FIGURE 7

INFORMATION HOT SPOTS

Human Hair

Caucasian Hair

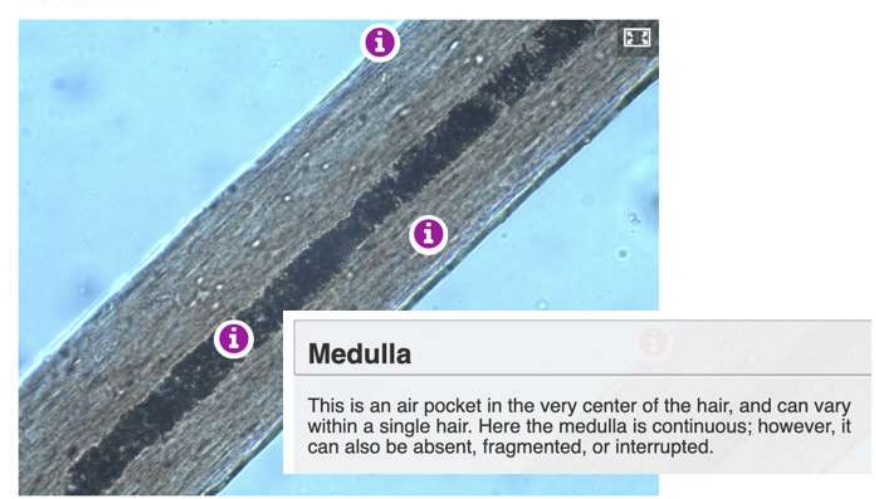


It is also important to have an organized, repeatable structure within the LMS, which gives students the same expectations for every unit throughout the course. Every weekly lab module is introduced with an overview page outlining the lab topics for the week, all of the reading assignments, videos, online materials, and assignments. Each lab contains corresponding instructional materials, pre-lab questions, worksheet assignment with post-lab questions, and a discussion forum covering the content for each lab. The LMS course structure uses modules to house all the learning materials, discussions, and assessments. Figure 8 shows the outline of the course organization.

\section{FIGURE 8 \\ LMS MODULE ORGANIZATION}

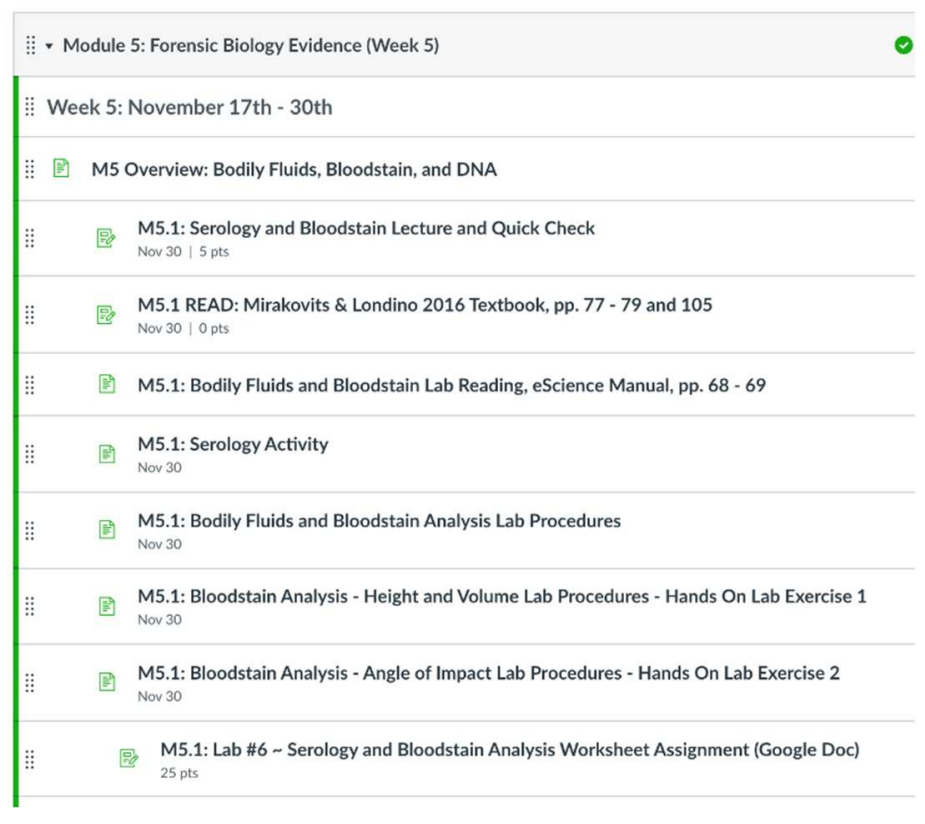

The LMS is also used to foster student to student interaction through the discussion board tool. Students also engage with the forensic science content in relation to everyday world issues through discussions. Realworld examples are used to engage students with the content. Articles, news stories, or other social media material is used for the students to review the concept related to the unit topic. They are then asked to formulate an opinion and share with their peers as well as respond to other students' posts. For example, how DNA profiling is used in commercial at-home DNA kits to link heredity and how this information is used in forensic case work.

\section{Hand-on Laboratory Exercises}

An online laboratory course can offer a similar experience to a face-to-face course while engaging the student in the content. Online students can expect to have hands-on experience which relates to everyday science. Laboratory kits were purchased through a commercial company which included multiple forensic science laboratory exercises similar to the face-to-face course. The logistics for students as well as administration support were taken into considerations throughout the development process.

First, research was done to discover commercial kits available in forensic science. Other sciences were also examined, such as biology and chemistry, which included experiments that could be apply to a forensic science course. It was extremely important to customize the lab kit, discarding experiments that were not part of the course and add ones that are. Next, plans were developed on how to incorporate the lab instructions into the LMS, so students didn't have to go between platforms. The lab kit material, including readings and laboratory procedures, are directly embedded into the LMS as pages, so students can easily 
navigate between the reading material that was created by the course instructor and the lab exercise instructions and procedures.

Top priorities were ensuring that students had easy access to ordering and receiving the laboratory kits as well as having the kits arrive in time to complete the lab exercises so students can submit the lab worksheets within the due date range. There were two options, students could directly pay for and order the lab kits from the supplier or the institution could pay in advanced for the lab kits and give enrolled students an access code to have the lab kit shipped to them directly. The second of the two was used in this course. In order for the institutions to pre-order and pay for the lab kits, student lab fees were used to purchase and ship the lab kits to enrolled students. First, students had to message the course instructor for the order code which also familiarized students with using the LMS messaging feature. Then students were required to upload the order confirmation as an assignment.

Other issues that came up with the lab kits were students not being familiar with the items or being able to identify materials used for each lab experiment or missing items from the lab kit. To solve these issues, first a video was recorded identify and displaying each item in the lab kit. This was done for the overall lab kit materials as well as for each individual lab exercise. The packing slip, seen in Figure 9, was also used to help students identify each item, both by labeling the name of the item and what lab exercise the item would be used for. To ensure that students had the items in time to complete the lab exercise or for materials to be re-shipped, an assignment was created for students to upload their packing slip with check marks next to each item showing it was in the lab kit received. The instructor could then work with students and the lab kit company on finding alternatives to missing items.

\section{FIGURE 9}

\section{LAB KIT PACKING SLIP WITH ITEMS LABELED}

$\begin{array}{llr}\mathbf{2} & \text { EA } 12 \text { Well Plate DNA \#7 (1), Illicit Drugs \#12 (1) } & \text { EQUP8157 } \\ \mathbf{1} & \text { EA Toothpicks, } 10 \text { ct DNA \#7 (9) } & \text { BAG8028 } \\ \mathbf{1} & \text { EA Pipettes ( } 10 \text { ct) Fingerprints \#5 (1), Bloodspatter \#6 (2), Illicit Drugs \#12 (2) } & \text { BAG1030 } \\ \mathbf{1} & \text { EA Protractor Crime Scene \#1, Bloodspatter \#6 } & \text { EQUP2046 } \\ \mathbf{1} & \text { EA Ruler 12" Plastic Clear Crime Scene \#1, Tire Tracks \#3, Fingerprints \#5, Bloodspatter \#6, QD/Inks \#10 } & \text { EQUP8035 } \\ \mathbf{1} & \text { EA Safety bag Crime Scene \#1, Fingerprints \#5, Bloodspatter \#6, DNA \#7, QD/Inks \#10 } & \text { EQUP8114 } \\ \mathbf{1} & \text { EA Clipboard (each) Bloodspatter \#6 } & \text { EQUP8132 } \\ \mathbf{1} & \text { EA Fingerprint Ink Pad Tire Tracks \#3, Fingerprints \#5 } & \text { EQUP9018 } \\ \mathbf{1} & \text { EA Hand Lens 3X 6X Fingerprints \#5, Fibers \#9, QD/Inks \#10, Illicit Drugs \#12 } & \text { EQUP8094 } \\ \mathbf{1} & \text { EA Tape Measure Ribbon Bloodspatter \#6 } & \text { EQUP8028 } \\ \mathbf{1} & \text { EA Metal Forceps Fibers \#9 } & \text { EQUP8179 } \\ \mathbf{1} & \text { EA Tracing Paper Sheet QD/Inks \#10 } & \text { EQUP9017 } \\ \mathbf{5} & \text { EA Cardstock Bloodspatter \#6 } & \text { EQUP2112 } \\ \mathbf{3} & \text { EA White Construction Paper Tire Tracks \#3 } & \text { EQUP2049 } \\ \mathbf{1} & \text { EA Anti-A Serum, } 3 \text { ml DNA \#7 } & \text { BTTL8227 }\end{array}$

\section{Virtual Laboratory Exercises}

Not all laboratory experiments done in the face-to-face course can be reproduced using the hands-on laboratory kit. This was due to availability of forensic specific materials, hazard concerns of multiple items, and location of the online environment instead of the institution laboratory. When students complete a laboratory course in a classroom setting, there is exposure to certain laboratory features, such as waste management, safety components, and equipment used in the lab. In order to create the same experience for online students, virtual tours were created of real forensic science crime laboratories. This included both the Indiana State Police (ISP) Crime Lab and the State Department of Toxicology Laboratory. Both 360degree photographs and still images were captured of different locations within each laboratory as well as images of equipment, lab features, and bench space. All the images were uploaded into Google Tour Creator 
and descriptions and explanations of the features in the lab seen in Figure 10. The tour allows students to "walk through" a real forensic science crime laboratory without having to step foot into the building.

\section{FIGURE 10 \\ VIRTUAL TOUR OF ISP CRIME LABORATORY}

Indiana State Police Crime Lab Tour"
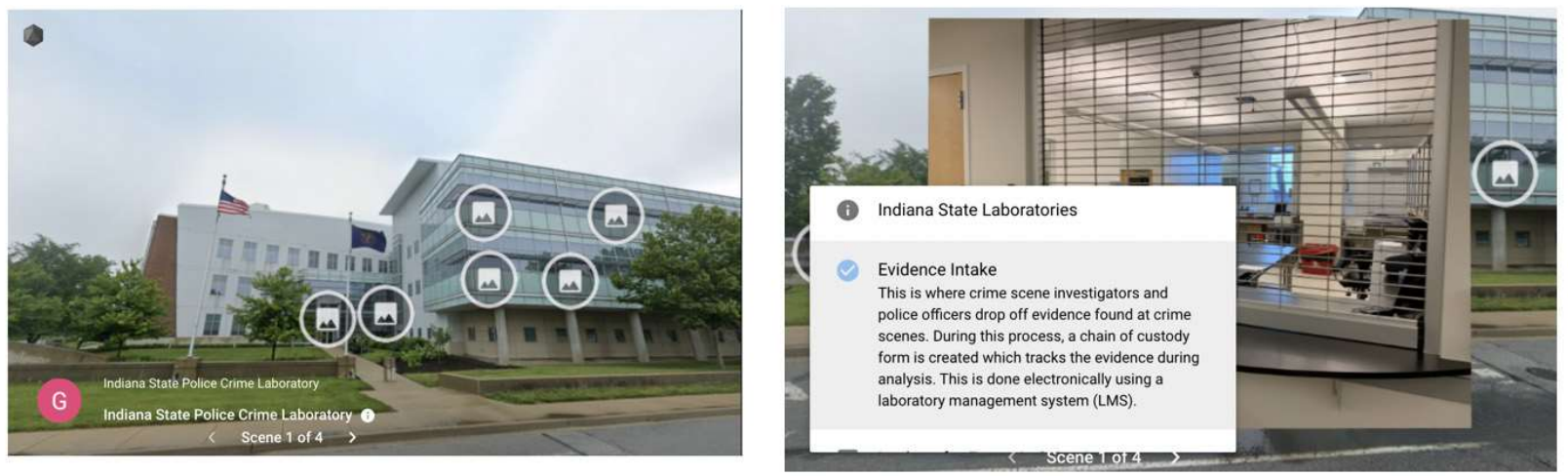

Many items that are used in a forensic laboratory course are hard to reproduce and can be difficult to have for all students and each semester. Therefore, many of the evidence that is used for analysis in the laboratory course is used for each section, each semester. For example, a set of 10 fired bullets and cartridge casings are used for students to examine class and individual characteristics of markings that can be compared in an examination. Other impression evidence, such as footwear, is also pre-made for students to examine in class. These types of materials are not available in commercial lab kits nor could be reproduced in mass for multiple online students enrolled in the course. Therefore, three-dimensional images were captures of both the bullet and cartridge casing as well as the shoes and casts. Students can manipulate the bullets and cartridge casings by increasing the size, rotation to see all sides, and pulling a ruler to measure the diameter. Student record the observations of multiple bullets and cartridge casings, noting the differences. Similar, shoe and cast 3D images seen in Figure 11 can be compared side by side. Students can take screenshots of the shoe patterns and look for similarities and differences between the evidence.

\section{FIGURE 11 \\ SHOE AND CAST THREE-DIMENSIONAL IMAGES}
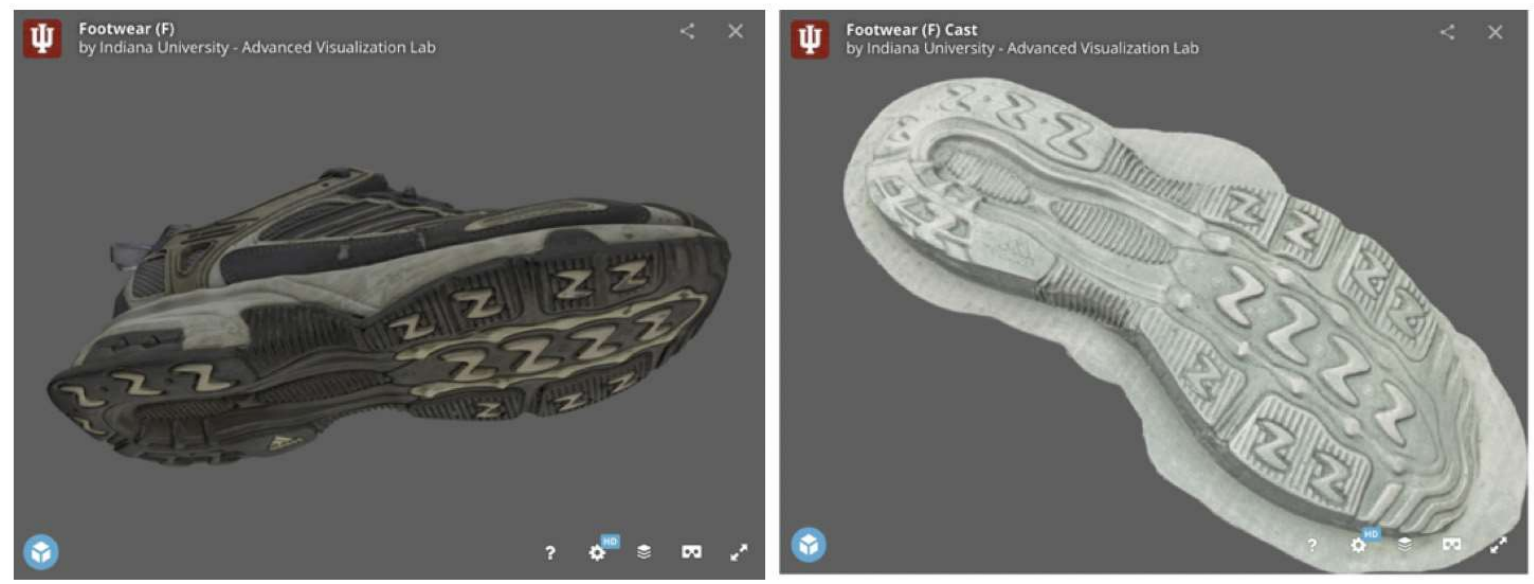
There was also the issue of using hazardous materials in specific lab exercises, such as explosives and bodily fluids. It was not possible to have these materials in the lab kit, therefore live demonstrations of the lab exercises with these materials were recorded by the instructor. The recordings recreated the lab exercises, exposing students to same observations as the face-to-face course. The explosive lab exercises introduce small particles of low explosives into an open flame as shown in Figure 12. The reaction of the explosives is recorded and students are required to write down their observations, such as the type of flame, presence of smoke, and the odor from the burnt explosive. An unknown explosive reaction was also recorded; therefore, students could use their observations of the known explosives and try to determine the identity of the unknown. Although it is important for students to have hands-on experience, there is benefit to having an expert demonstration to help students learn what's important and about the strategies used by the expert. Research shows that expert role modeling assists students in taking steps toward expertise themselves (Brown et al., 1989).

\section{FIGURE 12 \\ RECORDED LOW EXPLOSIVE REACTION}

\section{Burn Tests}

Video: Low Explosive Burn Tests

Watch this video demonstration of low explosive burn tests. to answer the questions on your lab report.

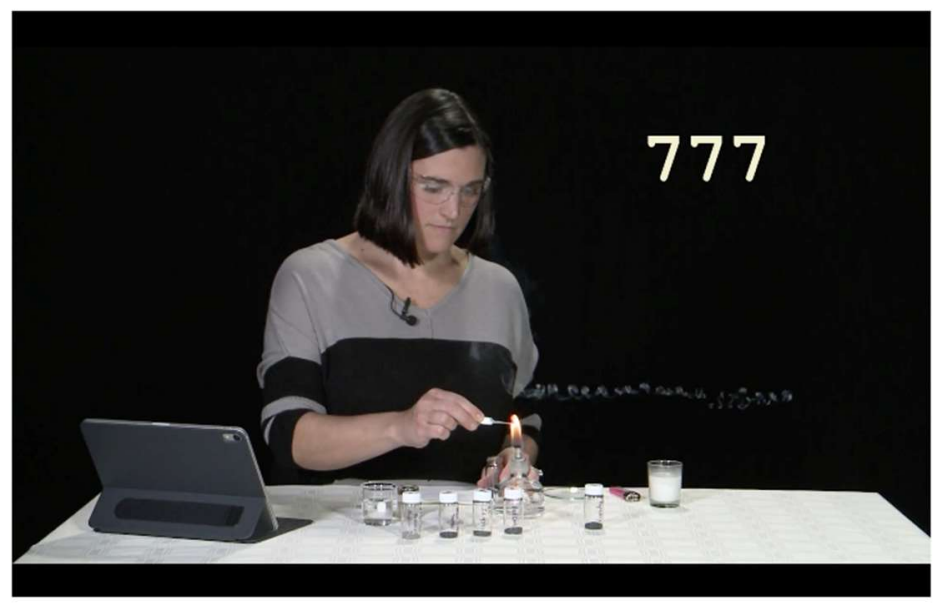

\section{CONCLUSION}

Creating an online laboratory course has many challenges but these can be overcome with the best practices in online teaching, such as Universal Design for Learning (UDL) and creating an authentic learning environment. The main principles of UDL were implemented throughout the design process to engage students, utilize multiple outputs for learning, and various assessments allowing multiple ways for students to demonstrate what they've learned. Discussion boards and simulative activities permit students to engage with each other and the course material. Students interact with the learning materials with different platforms, such as readings, lecture content, low-stakes questions, and laboratory exercises. Both formative and summative assessments are used throughout the course to gauge student learning. A learning environment was created in an organized fashion to direct students through the learning material through 
the module feature of the learning management system (LMS), which included a consistent structure for each unit. All the reading and lecture material, Quick Check assessments, simulative lab activity, lab procedures, lab worksheets and discussion boards are organized in the same order throughout each module. This guides students through the material and limits confusion.

The online laboratory course design reflects the face-to-face course design to allow for flexibility and to offer more course sections without space restrictions. The online version can be administered over multiple types of course session, including 6-weeks, 8-weeks, or 16-weeks, throughout the academic year. Due to the high demand for an online laboratory course, there is a wide variety of learners, some which have accessibility needs. To ensure the best learning experience and access for all learners, UDL, authentic learning environment design, and best practices for accessibility guided the course design.

Students were held at the forefront of the design experience while also leveraging the available university resources to support student success. The LMS was used to engage students with the learning material, each other, and the course instructor. Multiple formats provided varied student interaction with the course material, such as simulative activities and using interactive features like Google Docs. Discussion boards were used for students to interact with each other. In typical laboratory courses, students work in pairs, however, the online lab does not offer this. Therefore, weekly discussions over the unit topics were design to engage students with each other as well as the course content. Every course also requires a course instructor with an established presence in the online environment. LMS tools support instructors in this by creating announcements within the LMS as well as feedback in SpeedGrader provided students to interact with the course instructor. Weekly announcements, both written and recorded videos, can be used to update the students on assignments and key takeaways from the units. SpeedGrader used along with assignment specific rubrics can give students detailed feedback on discussion assignments and lab worksheets. It is important for the course instructor to engage with the students especially in an asynchronous online environment.

Mimicking the face-to-face course design was an important consideration for this online, therefore using both hands-on and virtual lab exercises were needed. Hands-on lab exercises using a customized, commercial laboratory kit allowed students to actively do the lab exercise, record observations, and come up with conclusions based on their results. To set students up for success, great care was taken to ensure students had access to the lab kit in a timely manner, as well as being familiar with all the lab items and what lab exercises used which items. This was done with a labeled packing slip, recorded demonstrations, and assignments students had to complete. For labs that could not be included in the lab kit, virtual lab exercises were designed. This included recorded, live demonstrations, interactive activities with threedimensional images, and virtual tours. These virtual labs allowed students to interact with the course material and participate in all the lab exercises in a remote environment.

\section{ACKNOWLEDGEMENTS}

Creating this laboratory course in the online environment included the work of many individuals, especially Maggie Ricci, Macy Morguson, and Caitlin Malone. Thank you for all your expertise and support.

\section{REFERENCES}

Basham, J., \& Marino, M. (2013). Understanding STEM education and supporting students through universal design for learning. Teaching Exceptional Children, 45(4), 8-15. https://doi.org/10.1177/004005991304500401

Belland, B.R. (2014). Scaffolding: Definition, current debates, and future directions. In M. Spector, M.D Merrill, J. Elen, \& M.J. Bishop (Eds.), Handbook of Research on Educational Communications and Technology (pp. 505-518). Springer-Verlag. https://doi.org/10.1007/978-1-4614-3185-5_39 
Bernard, R.M., Borokhovski, E., Schmid, R.F., Tamim, R.M., \& Abrami, P.C. (2014). A meta-analysis of blended learning and technology use in higher education: From general to the applied. Journal of Computing in Higher Education, 26, 87-122. https://doi.org/10.1007/s12528-013-9077-3

Bransford, J.D., Brown, A.L., \& Cocking, R.R. (2004). The design of learning environments. In N.R. Council (Ed.), How People Learn: Brain, Mind, Experience, and School (pp. 131-154). The National Academy Press.

Brinson, J.R. (2015). Learning outcome achievement in non-traditional (virtual and remote) versus traditional (hands-on) laboratories: A review of the empirical research. Computers \& Education, 87, 218-237. https://doi.org/https://doi.org/10.1016/j.compedu.2015.07.003

Brown, J.S., Collins, A., \& Duguid, P. (1989). Situated cognition and the culture of learning. Educational psychologist, 18(1), 32-42. https://doi-org.proxyiub.uits.iu.edu/10.3102/0013189X018001032

Chen, B., Bastedo, K., \& Howard, W.S. (2018). Exploring design elements for online stem courses: active learning, engagement \& assessment design. Online Learning, 22(2), 59-75. https://doi.org/doi:10.24059/olj.v22i2.1369

Cummings, S.M., Foels, L., \& Chaffin, K.M. (2013). Comparative analysis of distance education and classroom-based formats for a clinical social work practice course. Social Work Education, 32(1), 68-80. https://doi.org/10.1080/02615479.2011.648179

Davenport, J.L., Rafferty, A.N., \& Yaron, D.J. (2018). Whether and how authentic contexts using a virtual chemistry lab support learning. Journal of Chemical Education, 95(8), 1250-1259. https://doi.org/10.1021/acs.jchemed.8b00048

Ellis, H., \& Barnes, E. (2020). Handwritten or typewritten: Does it really matter? Instructor feedback and student perceptions of connectedness. Education, 141(1), 1-10.

Gravel, J.W., Edwards, L.A., Buttimer, C.J., \& Rose, D.H. (2017). Universal design for learning in postsecondary education: Reflections on principles and their application. In S.E. Burgstahler (Ed.), Universal Design in Higher Education: From Principles to Practice (2nd ed., pp. 81-100). Harvard Education Press.

Hartnett, M. (2012). Relationships between online motivation, participation, and achievement: More complex than you might think. Journal of Open, Flexible, and Distance Learning, 16(1), 28-41.

Herrington, J., \& Oliver, R. (2000). An instructional design framework for authentic learning environments. Educational Technology Research and Development, 48(3), 23-48.

Herrington, J., Reeves, T.C., \& Oliver, R. (2014). Authentic learning environments. In J.M. Spector, M.D. Merrill, J. Elen, \& M.J. Bishop (Eds.), Handbook of Research on Educational Communications and Technology (pp. 401-412). Springer New York. https://doi.org/10.1007/978-1-4614-3185-5_32

Land, S., Hannafin, M., \& Oliver, K. (2012). Student-centered learning environments: Foundations, assumptions, and design. In D. Jonassen \& S. Land (Eds.), Theoretical Foundations of Learning Environments (2nd ed., pp. 3-25). Taylor \& Francis.

Lou, Y., Bernard, R.M., \& Abrami, P.C. (2006). Media and pedagogy in undergraduate distance education: A theory-based meta-analysis of empirical literature. Educational Technology, Research, and Development, 54(2), 141-176. https://doi.org/10.1007/s11423-006-8252-x

Merrill, M.D. (2013). First principles of instruction: Identifying and designing effective, efficient, and engaging instruction. John Wiley and Sons, Inc.

Moore, E.J. (2010). Lesson: What is UDL? Retrieved from https://learn.canvas.net/courses/2721/pages/lesson-what-is-udl?module_item_id=241658

Moosvi, F., Reinsberg, S., \& Rieger, G. (2019). Can a hands-on physics project lab be delivered effectively as a distance lab? International Review of Research in Open and Distance Learning, 20(1), 22-42. https://doi.org/10.19173/irrodl.v20i1.3782

Rogers-Shaw, C., Carr-Chellman, D.J., \& Choi, J. (2018). Universal design for learning: Guidelines for accessible online instruction. Adult Learning, 29(1), 20-31. https://doi.org/10.1177/1045159517735530 
Sher, A. (2009). Assessing the relationship of student-instructor and student-student interaction to student learning and satisfaction in web-based online learning environment. Journal of Interactive Online Learning, 8(2), 102-120.

Simonson, M., Schlosser, C., \& Orellana, A. (2011). Distance education research: A review of the literature. Journal of Computing in Higher Education, 23, 124-142. https://doi.org/10.1007/s12528-011-9045-8

Simonson, M., Smaldino, S., Albright, M., \& Zvacek, S. (2012). Teaching and learning at a distance: Foundations of distance education (5th ed.). Boston, MA: Pearson Education.

Szeto, E., \& Cheng, A.Y.N. (2016). Towards a framework of interactions in a blended synchronous learning environment: What effects are there on students' social presence experience? Interactive Learning Environments, 24(3), 487-503. https://doi.org/10.1080/10494820.2014.881391

Theyßen, H., Struzyna, S., Mylott, E., \& Widenhorn, R. (2016). Online physics lab exercises - a binational study on the transfer of teaching resources. International Journal of Science \& Mathematics Education, 14(5), 865-883. https://doi.org/10.1007/s10763-014-9613-2

Wavle, S., \& Ozogul, G. (2019). Investigating the impact of online classes on undergraduate degree completion. Online Learning, 23(4), 281-295. doi:10.24059/olj.v23i4.1558

Winkelmes, M-A. (2016). The unwritten rules: Decode your assignments and decipher what's expected of you. [PDF] tilthighered.com. Retrieved from https://tilthighered.com/assets/pdffiles/Template.pdf

Winkelmes, M-A., Bernacki, M., Butler, J., Zochowski, M., Golanics, J., \& Weavil, K.H. (2016). A teaching intervention that increases underserved college students' success. Peer Review, 18(1/2). https://www.aacu.org/peerreview/2016/winter-spring/Winkelmes 